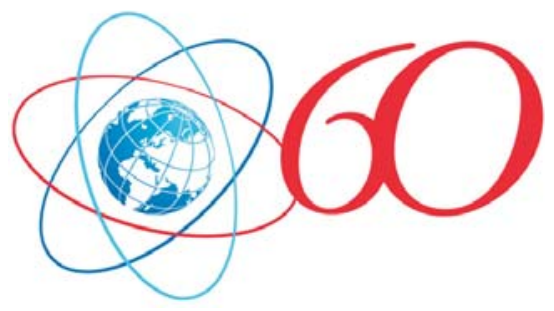

К концу 50-х годов вузовская наука достигла значительных успехов в различных областях. В связи с этим было принято решение об учреждении 26 научных журналов высшей школы «Известия высших учебных заведений» Министерства высшего и среднего специального образования СССР по различным областям науки и техники. Издание этих журналов поручалось вузам, достигшим значительных успехов в соответствующей отрасли.

Издание журнала «Известия высших учебных заведений по разделу Радиотехника» было поручено Киевскому политехническому институту (КПИ), а ответственным редактором журнала был назначен выдающийся ученый, заведующий кафедрой радиопередающих устройств КПИ и лаборатории СВЧ института электродинамики АН УССР, д.т.н., член-корреспондент АН УССР профессор Семен Исаакович Тетельбаум. Заместителем ответственного редактора был назначен доцент той же кафедры Ярослав Карпович Трохименко.

В состав редакционной коллегии журнала были назначены ведущие специалисты высшей школы в области радиотехники и электроники. В дальнейшем осуществлялось периодическое обновление состава редакционной коллегии, что способствовало своевременному отображению в журнале наиболее актуальных проблем развития отечественной радиоэлектроники (теоретические основы радиотехники, радиолокация, радиотехнические устройства и системы, электронные и твердотельные приборы СВЧ, теория радиотехнических цепей, транзисторная схемотехника, фазированные антенные решетки, обработка сигналов и т.д.).

Журнал начал выходить в свет с января 1958 г. шесть раз в год объемом 10 печатных листов в каждом выпуске. С первых выпусков в журнале публиковались обзорные и оригинальные статьи как известных ученых, так и молодых авторов. Редакционная коллегия журнала с самого начала своей деятельности предъявляла высокие требования к качеству публикуемых статей, объективно и благожелательно относясь к авторам и стремясь к представле-

\section{ШЕСТЬДЕСЯТ ЛЕТ ЖУРНАЛУ «ИЗВЕСТИЯ ВЫСШИХ УЧЕБНЫХ ЗАВЕДЕНИЙ. РАДИОЭЛЕКТРОНИКА»}

нию в журнале всех научных школ высших учебных заведений страны по профилю журнала.

В 1959 г. ответственным редактором журнала был назначен известный специалист в области радиотехники, один из пионеров строительства крупных радиостанций в СССР, основатель радиотехнической школы в Украине, заведующий кафедрой теоретических основ радиотехники (ТОР) КПИ, проф. Владимир Васильевич Огиевский.

С 1965 г. в США начала издаваться англоязычная версия журнала под названием «Radioelectronics and Communications Systems», сначала фирмой «Фарадей Пресс», а впоследствии «Аллертон Пресс».

В 1967 г. название журнала было изменено на «Известия высших учебных заведений Министерства высшего и среднего специального образования СССР по разделу «Радиоэлектроника». Журнал стал выходить в свет ежемесячно объемом 8 печатных листов в каждом выпуске.

В 1971 г. главным редактором журнала был назначен известный специалист в области теории цепей, профессор кафедры ТОР Киевского политехнического института, д.т.н. Ярослав Карпович Трохименко, а заместителем главного редактора к.т.н., доцент той же кафедры, Анатолий Викторович Кисляковский.

Успешному становлению и изданию журнала способствовали добросовестный безвозмездный труд членов редколлегии, а также высокий уровень научных исследований в различных направлениях на радиотехническом факультете КПИ, который в то время являлся ведущим в СССР (19 сотрудников факультета были удостоены Государственных премий СССР и УССР в области науки и техники).

В 1982 г. решением Госкомитета СССР по печати объем каждого выпуска журнала был уменьшен с 8 до 6 печатных листов при сохранении формата.

Следует отметить, что к 1988 г. журнал «Известия высших учебных заведений. Радиоэлектроника» стал лучшим научным журналом высшей школы. Годовая подписка на журнал достигла более 5000 экземпляров (только в КНР более 500 эк- 
земпляров), журнал распространялся в 126 странах мира. Публикации в журнале обеспечивали их авторам гранты фонда Сороса.

После распада СССР учредителями журнала «Известия высших учебных заведений. Радиоэлектроника» стали Министерство образования и науки Украины и Киевский политехнический институт. Объем каждого выпуска журнала формата А5 был установлен в 5 печатных листов, а для сокращения технологических затрат каждые два выпуска объединялись общей обложкой.

В 1991 г. был заключен договор с американской фирмой Allerton Press, Inc. о переводе и изготовлении в КПИ «саmera-ready» нашего журнала на английском языке. В 1996 году с помощью фонда «Відродження» редакция приобрела полиграфическое оборудование и сотрудниками редакции начал осуществляться полный издательский цикл - от редактирования и компьютерного набора статей до изготовления и экспедирования тиража журнала. Это позволило в экономически тяжелые годы существенно снизить типографские расходы, значительно повысить качество полиграфического исполнения, а самое главное - сохранить издание журнала. За все это особая благодарность главному редактору Я.К. Трохименко и его заместителю А.В.Кисляковскому.

Начиная с 2007 г. распространителем англоязычной версии журнала («Radioelectronics and Communications Systems») стал издатель Springer, что позволило распространять журнал не только в виде годовых подписок, но и отдельными статьями. Количество скачиваний каждой статьи позволило оценить востребованность материалов журнала в мире.

В 2009 году главным редактором журнала был назначен известный ученый в области теории и техники антенн и микроволновых устройств, Заслуженный деятель науки и техники Украины, заведующий кафедрой ТОР КПИ, д.т.н., профессор Федор Федорович Дубровка. При этом была существенно обновлена редколлегия журнала, куда были введены известные ученые, возглавляющие успешно работающие научные школы из различных областей радиоэлектроники. Состав редколлегии стал обновляться каждый год, что позволило обеспечить международное «боевое ядро» рецензентов по самым актуальным направлениям развития современной радиоэлектроники.

В это же время изменилось оформление журнала, что позволило ему выйти на соответствую- щий международный уровень. С 2010 года журнал издается в формате А4. В 2016 издатель журнала Национальный технический университет Украины «Киевский политехнический институт» - стал членом организации Crossref, что позволило присваивать всем статьям, публикуемым в журнале, международный идентификатор DOI (Digital Object Identification). За счет обновления печатного оборудования, отдельные рисунки в журнале стали печататься в цвете, что увеличило читаемость и привлекательность его статей.

С переходом в 2012 году сайта журнала на новую платформу OJS (Open Journal System), предоставленную Ассоциацией УРАН, был обеспечен еще один способ подачи статей — on-line - что позволило значительно расширить географию авторов статей (Украина, Россия, Индия, Китай, Мексика, Египет, Малайзия, Ирак, Алжир, Польша, Великобритания, Италия, Бразилия, Франция, Южная Корея и др., всего 23 страны). Также, это дало возможность распространять русскоязычную версию журнала аналогично ее англоязычной версии - отдельными статьями. Во всем этом большая заслуга ответственного секретаря журнала Сергея Николаевича Литвинцева.

Хочется отметить, что к своему 60-летнему юбилею журнал стал истинно международным и обеспечил себе лидирующее положение среди аналогичных журналов на территории бывшего СССР. Он индексируется в международных базах SCOPUS, INSPEC, Google Scholar, Academic OneFile, EI-Compendex, Gale, OCLC, SCImago, Summon by Serial Solutions, ВИНИТИ и имеет SNIP-2016 = 0,462 (Source Normalized Impact per Paper) и SJR-2016 = 0,2 (SCImago Journal Rank). Члены редколлегии журнала - это ученые из разных стран (Украина, Великобритания, Дания, Мексика, Россия, Польша, Германия).

Поздравляю авторов и читателей журнала с этой знаменательной датой. Выражаю искреннюю благодарность членам редколлегии и рецензентам журнала за их нелегкий труд и желаю всем крепкого здоровья, больших творческих успехов и продолжения публикации Ваших научных достижений на страницах нашего журнала.

Главный редактор Ф.Ф.Дубровка 